\title{
Origem e transformação do enraizamento sindical do Partido Justicialista (Argentina) e do Partido dos Trabalhadores (Brasil)
}

O estudo da institucionalização dos partidos na América Latina proposto por Mainwaring e Scully (1996) supôs um marco nos estudos sobre as realidades partidárias na região, já que conceberam a institucionalização como padrões de interação da concorrência político-partidária, e a continuidade e regularidade das organizações e procedimentos (MAINWARING e SCULLY, 1996, p. 4); ou seja, medem a institucionalização dos partidos para reproduzir sua organização e apoio eleitoral ao longo do tempo (LEIRAS, 2004, p. 31), com o qual incorporam à dimensão das relações interpartidárias, comumente interpretadas desde a noção clássica de sistema de partidos, a preocupação interna da vida partidária ${ }^{1}$.

A partir dessa perspectiva, no que se refere à dimensão organizativa partidária, Mainwaring e Scully consideram a estruturação interna ou solidez organizativa dos partidos, e o enraizamento dos partidos na sociedade. O primeiro destes dois aspectos tem sido enfocado pela maioria dos estudos posteriores à proposta destes autores, especialmente recuperando a diferença formal e informal da institucionalização partidária (LEVITSKY, 2005; PEDROSA, 2005; FREIDENBERG e LEVITSKY, 2007; entre outros).

Uma primeira versão deste ensaio foi apresentada no IX Congresso Argentino de Ciência Política realizado em agosto de 2009 na cidade de Santa Fé, onde foi reconhecido com o "Prêmio María Grossi à Investigação sobre Política Latino-americana". Agradeço os comentários de Iván Llamazares, Flavia Freidenberg, Helcimara Telles, Agustín Ferraro, Cintia Pinillos, Nélida Perona, Cecilia Hernández Cruz, Peter Byrle e Vicente Palermo. 
O que concerne ao enraizamento dos partidos na sociedade, aspecto nodal para este ensaio, a perspectiva de Mainwaring e Scully somente abordou a área das preferências do eleitorado (reconhecendo a volatilidade das mesmas), através de um olhar sistêmico do enraizamento, o que permite reconhecer se este é um fenômeno presente ou ausente na totalidade dos partidos do sistema.

Tal ponto de vista os levou a propor uma divisão entre países com partidos que conseguem "encapsular" as organizações sociais de importância - como Venezuela, Chile, Costa Rica ou Uruguai - e outros países cuja debilidade de enraizamento tem sido uma constante, como nos casos de Brasil, Equador e Bolívia (MAINWARING e SCULLY, 1996, p. 10). Não obstante, essa perspectiva "eleitoral" e "sistêmica" do enraizamento oculta a possibilidade de ver a inserção dos partidos em organizações da sociedade civil, e ofusca a oportunidade de observar o enraizamento efetivo de algum partido em um sistema incoativo.

Considerando essa crítica, o interesse deste ensaio radica em aproximar-se ao estudo do enraizamento partidário na sociedade, mas não somente por uma perspectiva eleitoral, senão também por um enfoque que recupere as vicissitudes dos próprios atores partidários e da sociedade civil - neste caso o sindicalismo -, como também analisar aqueles partidos que possuem uma forte vinculação com a sociedade civil, apesar de formar parte dos sistemas fragilmente institucionalizados nesta dimensão, como são os que se propõe abordar neste artigo: o Partido dos Trabalhadores (PT), no caso brasileiro, e o Partido Justicialista (PJ), na Argentina.

Para tal tarefa, serão observados alguns elementos, tais como: a) a origem do enraizamento sindical dos partidos em análise, b) a dinâmica da concorrência partidária, c) a concorrência sindical, e d) o interior dos partidos e sindicatos em estudo, durante as décadas de 1980 e de 1990. A seleção destas dimensões buscou avaliar se a transformação ou fortalecimento das raízes sindicais do PT e do PJ no Brasil e na Argentina, respectivamente, está relacionada com a dependência da trajetória de origem, a possibilidade partidária de ser governo ou oposição, a inclinação sindical de vincular-se com esses partidos em um contexto de transformação social, política e econômica, estabelecendo um claro panorama para reconhecer quanto de "revolução sindical" teve a chegada do PT em 2002 no Brasil, e quão "desindicalizado" estava o peronismo ao momento da eleição de Néstor Kirchner. 


\section{Origem}

\section{Argentina: da origem nacional e popular às tentativas truncadas do neoperonismo sindical (1945-1983)}

As origens do movimento operário argentino são de longa data. A partir dos primeiros anos do século XX, o pertencimento político e ideológico do movimento operário organizado se dispersou ideologicamente (MATSUSHITA, 1986, p. 23-31), pelo menos até a fundação da CGT em 1930, quando o movimento operário adquiriu maior nível de estruturação interna. Em contrapartida, deixou ainda sem resolver a politização da classe operária e sua manifestação através dos partidos políticos (DEL CAMPO, 1983, p. 64; TORRE, 1999, p. 177).

Durante o processo político iniciado após o golpe do Estado de 1943, Juan Domingo Perón colocou em funcionamento uma série de reformas sociais focalizadas no trabalhador (obtendo grande aprovação do mundo operário-sindical), o que por sua vez o consolidou como figura política. Esses aspectos, somados ao apoio popular de 17 de outubro de 1945, e à dispersão da oposição, entre outros, o lançaram à vitória como presidente em 1946, momento fundacional do "vínculo perdurável" entre sindicalismo e peronismo.

A origem e as modalidades de aliança partidária-sindical na Argentina são um importante debate acadêmico e político. A esse respeito, a primeira interpretação sobre as origens do peronismo e seu vínculo operário-sindical corresponde a Gino Germani, que advertiu que as grandes quantidades de nova mão-de-obra conglomerada nas principais cidades da Argentina sucumbiriam ante qualquer oferta de participação política, mesmo que significasse a via "irracional" do cativeiro sob o influxo "autoritário" nacional popular, que propunha o peronismo (GERMANI, 1962, p. 142, 231, 251).

Durante a década de 1970, Murmis e Portantiero (1971) enfocam o surgimento do peronismo como uma aliança de fragmentos de classes possibilitada graças à força do sindicalismo na canalização de demandas e mobilização de setores populares e, por outro lado, pela reconfiguração das classes dominantes dos anos 1930 até 1943, desde um padrão restritivo a um de corte popular.

Na década de 1980, Juan Carlos Torre voltará a repensar as origens do peronismo, colocando em destaque a politização da classe trabalhadora que levou adiante J. D. Perón para transformar ao sujeito social - cujas reivin- 
dicações trabalhistas o sindicalismo já havia começado a impulsionar - em um "novo" sujeito político (TORRE, 1990 e 1999, p. 176).

Nos anos 1990, surgiram novas interpretações, como por exemplo a de Sidicaro (1999, p. 156), para quem o vínculo entre peronismo e sindicalismo se entende pela combinação entre a crise de dominação da "década perdida" de 1930, o crescimento de um Estado intervencionista, o papel dos promotores do peronismo e a politização dos conflitos sociais que habilitou o peronismo, mas não pelas prerrogativas ou legislação trabalhista que este último concedeu à classe operária. No novo século, têm aparecido outras interpretações como a de Di Tella (2004, p. 11-12, 441-443), que propõe uma leitura da origem do peronismo partindo da matriz nacional popular, que Argentina peronista compartilha com outros países latino-americanos.

Assim, além das múltiplas interpretações sobre a origem do peronismo e sua relação operário-sindical, é interessante notar como, uma vez gerado o sincretismo "singular" entre peronismo e sindicalismo, a morfologia que adquire o laço durante a primeira década peronista (1946-1955) produziu uma tendência de sindicalização do partido, na qual o mundo operário-sindical foi a "coluna vertebral do movimento", mas Perón foi quem ocupou, acima destes, a direção do partido. Desta forma, Perón contou com a liderança suficiente para restringir as tentativas da vertente sindical dentro do peronismo, que buscava formalizar sua participação, como, por exemplo, em 1946, quando estes haviam dado impulso à formação do Partido Laborista (PL), cuja afiliação ao partido era levada adiante de maneira coletiva, que foi vetada por Perón. Dessa maneira, o Partido Peronista conformou-se como um movimento ou partido carismático em que a participação sindical se inseria de maneira institucionalizada, mesmo que não formalizada. Entretanto, esse movimentismo peronista não limitou a tradição organizativa intrassindical de longa data que, como será visto, ocorreu no Brasil (LEVITSKY, 2005, p. 50; DE RIZ, 1986, p. 674; MUSTAPIC, 2002).

Uma vez que o vínculo partidário-sindical se solidificou na década 1946-1955, este sobreviveu aos momentos de maior tensão durante o período 1955-1983. Quando em 1955 a "Revolução Libertadora" dissolveu o Partido Peronista e interveio a CGT, a influência do peronismo na política argentina persistiu pela força dos sindicatos. Em 1957, estes formaram as “62 Organizações Peronistas”, único referente organizado da classe operária durante as décadas seguintes e que até mesmo deram impulso a fórmulas 
partidaristas que referenciavam a vertente peronista (como a UP, União Popular, e o Partido Laborista, PL) que não foram proscritas pelo governo de Pedro Eugenio Aramburu (SIDICARO, 1999, p. 169; LEVITSKY, 2005, p. 100; CARLES, 2001 p. 261). Assim, começa o que desde a perspectiva sindical impulsionada por Augusto Vandor se conheceu como o "peronismo sem Perón", ou seja, a continuidade do movimento sem o líder (que se encontrava exilado), ou a tentativa de voltar ao laborismo incompleto de 1946 sem deixar de ser peronistas.

Essa proposta de modificar a morfologia do laço partidário-sindical, colocando a estrutura sindical como o eixo articulador do movimento, se encontrou em reiteradas oportunidades com o veto direto e indireto do próprio Perón, que alentou ao sindicalismo quando este era a única via de manter vivo o espírito peronista, e o despojou de protagonismo, quando adquiria maior relevância que a sua própria. Neste sentido, a tentativa de retorno do próprio Perón em 1964, ou a chegada de sua nova esposa (Maria Estela Martínez de Perón) em 1965, pode ser entendida como um "chamado à ordem" do mundo operário, organizado por parte do próprio Perón, que, após o golpe militar de 1966, consolidou paradoxalmente (uma vez mais) o "peronismo de Perón” como expressão do mundo operário-sindical na política.

Após o "Onganiato", a possibilidade de regresso de Perón estava marcada pela mudança do interior do próprio peronismo, o qual não somente habitava a antiga "coluna vertebral" operária-sindical depois dos câmbios neoperonistas, como também habitava uma nova ala (cujo enfrentamento com a burocracia sindical era evidente, tal como se demonstra nos enfrentamentos de 20 de junho de 1973 em Ezeiza), liderada pela Juventude Peronista e aqueles setores peronistas de esquerda que após a Revolução Cubana viam no peronismo o caminho para o socialismo (DE RIZ, 1986, p. 675; LEVITSKY, 2005, p. 60).

Esse mal-estar no interior do peronismo não se resolveu com o terceiro governo de Perón (1973-1976), senão que se viu agravado pela falta de resolução que este propôs e seu imediato falecimento em 1974, fatos que levaram à dispersão entre esquerda e direita do peronismo, e que foram a antessala de um processo de desintegração social e política levada adiante pelo golpe militar de 1976 - processo do qual o sindicalismo não saiu ileso,

Governos de fato de J. C. Onganía, R. Levingston e A. Lanusse, entre 1966 e 1973. 
já que se fragmentou entre aqueles setores que se consideravam herdeiros das "62 Organizações", que preservaram uma característica "participacionista" em relação ao regime autoritário e que logo se agruparam na CGT da Rua Azopardo, e os setores de centro-esquerda, chamados de "os 25", ou "confrontacionistas" com o regime militar, que se agruparam em 1980 em torno à CGT da Rua Brasil. Vazios de liderança, fragmentados ideologicamente, e abatidos fisicamente, o regresso da democracia em 1983 foi um cenário em que uma vez mais se colocaria em jogo o peronismo, e com ele, o papel do sindicalismo.

\section{Brasil: da origem nacional popular truncada ao surgimento de um novo sindicalismo político (1945-1984)}

A relação entre o mundo operário organizado e a política partidária é igualmente de longa data no Brasil. Em primeiro lugar, entre anarquistas e sindicalistas que desde 1903 confluíram na Confederação Operária Brasileira, e após a Revolução Russa, entre comunistas e sindicalistas que formaram em 1922 o Partido Comunista Brasileiro, e em 1929 a Confederação Geral do Trabalho. Entretanto, o laço partidário-sindical esteve debilmente institucionalizado, sendo este vazio aproveitado pelo populismo de Getúlio Vargas, que, desde 1930, a partir do Estado, impulsionou a organização dos sindicatos fazendo com que, na concessão de importantes direitos ao trabalhador, os vinculara com a política de uma forma "paternalista" (COLLIER e COLLIER, 1991, p. 70; RODRIGUES, 1969, p. 90-98, JAGUARIBE, 1987, p. 228).

Uma vez finalizado o impulso inicial do Estado Novo, Vargas propiciou, em meados da década de 1940, a formação dos partidos políticos, o Partido Social Democrático (PSD) e o Partido Trabalhista Brasileiro (PTB). O primeiro estava orientado às elites estaduais, principalmente dos Estados periféricos, onde a aura conservadora era maior; e o segundo, orientado ao setor popular urbano, apenas sindicalizado (DI TELLA, 1998, p. 156; GOMEZ e D'ARAUJO, 1989, p. 9). Desta forma, contrariamente ao acontecido na Argentina, a possibilidade de configurar um partido de massas, em que a representação sindical tivesse um papel determinante, se viu truncada. Isso ocorreu não somente pelos desígnios do próprio Vargas, mas também pela força dos setores oligárquicos e conservadores, e inclusive pela própria debilidade dos setores sindicais para levar adiante um movimento como o peronismo. 
Este panorama de debilidade sindical e sua consequente inexpressividade política foram revertidos lentamente pelo forte impacto do golpe militar de 1964, que esvaziou forçadamente (em um primeiro momento), o espaço de representação sindical (sobretudo eliminando o direito à greve), mas que paradoxalmente deixou um vazio para gerar um novo sindicalismo. Assim, durante o grande desenvolvimento industrial de finais dos anos 1960, começou a gestar-se uma nova expressão sindical, chamada novo sindicalismo, que destacava o caráter corporativo e burocrático do sindicalismo de velha estirpe e seu caráter "pelego", ao ser um parceiro obediente do Estado (SANTANA, 1999, p. 109).

Esse novo sindicalismo estava longe de ser um grupo homogêneo, já que em seu interior interagia uma pluralidade de expressões. Em primeiro lugar, se encontra um grupo autodenominado como "Oposição Sindical", liderado por José Ibrahim , um “(...) grupo relativamente inexpressivo, [que] compreendia militantes católicos e remanescentes de pequenos grupos de esquerda” (MENEGUELLO, 1989, p. 49).

Outro setor, conhecido como "Unidade Sindical”, era encabeçado por Joaquim dos Santos Andrade (Joaquinzão $o^{4}$ ), e se encontrava ligado diretamente ao establishment sindical, o PCB, e o Partido Comunista do Brasil (PC do B), e insistia na necessidade de unir-se ao Partido Movimento Democrático Brasileiro (PMDB) em prol da abertura democrática.

Contrariamente a este setor, os membros da "Unidade Sindical"

(...) defendiam a autonomia dos sindicatos frente ao Estado (quer dizer, o fim do direito à intervenção do Ministério do Trabalho nos assuntos internos dos sindicatos), mas não a liberdade sindical, se com isso se entende a completa liberdade de organização sindical por parte dos trabalhadores, sem necessidade de reconhecimento do Estado (RODRIGUES, 1991, p. 28).

Outra das expressões era um grupo heterogêneo, que em um primeiro momento se denominou "Independentes", logo "Autênticos" e posteriormente "Combativos", que nesse momento não tinham uma postura ideológica e política consolidada, senão que se diferenciavam do resto “(...) pela independência frente ao aparato estatal e pelo intuito de mobilizar a categoria,

Presidente do Sindicato de Osasco/SP nas greves de 1968.

4 Presidente do Sindicato dos Metalúrgicos de São Paulo/SP. 
enquanto principal recurso de poder" (OLIVEIRA, 1988, p. 46), entre eles, por exemplo, se sobressaía Luis Inácio Lula da Silva ${ }^{5}$.

No final da década de 1970, desencadeou-se uma onda de greves que paralisaram a região do $\mathrm{ABC}$ Paulista e as demais cidades industriais do interior, que tiveram influência em uma série de mudanças, entre elas: a) se alteraram os padrões de ação do governo autoritário, já que a proibição do direito à greve se havia rompido, e com isso começava a quebra do seu poder; b) trouxe um desequilíbrio de poder ao interior do sindicalismo, pois estas greves não foram orquestradas desde o sindicalismo oficial, mas sim desde os novos setores; e c) a partir desta demonstração de poder ficou em evidência a possibilidade de que o sindicalismo se configurasse como ator político, inclusive com a capacidade de representação de importantes setores da sociedade (MENEGUELLO, 1989, p. 55). Neste importante momento de mobilização política e sindical, no dia 10 de fevereiro de 1980 se forma o Partido dos Trabalhadores, e em 1981 a Comissão Nacional Pró-Central Única dos Trabalhadores, que em 1983 daria finalmente origem à CUT (Central Única dos Trabalhadores).

Repensando as origens do PT, cabe ressaltar que, ainda que tenha sido um partido orquestrado desde uma pluralidade de setores, e que tenha sido a fragmentação sindical a que ocupou, ao menos em seu início, a vanguarda (contrariamente ao que se viu com o peronismo e inclusive com o PTB no varguismo), o PT foi o primeiro partido que por fora do Estado, mas não por fora do sindicalismo oficial, a classe trabalhadora se apresentou na arena política expressando seus interesses, com o qual propõe uma partidização do sindicato (RODRIGUES, 1990, p. 42; MENEGUELLO, 1989). Nesta construção, o PT não seguiu os padrões dos partidos de esquerda latino-americanos, que em parte respondiam ao paradigma leninista de partido, no qual “(...) o sindicato era a corrente de transmissão da linha do partido, um instrumento do qual a classe operária perde sua autonomia frente ao Estado" (BALBI, 1990, p. 101). Por último, como destaca J. A. Moisés no fragmento a seguir, a novidade do PT radicaria no seu nascimento "desde baixo":

É bem conhecida a novidade apresentada pelo PT na história política brasileira: não só o PT rompeu com a velha tradição elitista de partidos organizados de cima para 
baixo - na verdade o PT foi o primeiro partido, nos últimos cinqüenta anos, a nascer de iniciativa de "baixo" - como também rompeu a tradição de partidos que nasciam dentro do Estado ou por iniciativa do Estado (MOISÉS, 1986, p. 182).

Não obstante, esta afirmação taxativa de J. A. Moisés deve ser relativizada em parte, já que dificilmente se pode afirmar que o PT nas suas origens tenha se formado completamente a partir dos "de baixo". Os que deram ao PT sua morfologia foram líderes sindicais, integrantes da Igreja Católica, grandes intelectuais da intelligentsia brasileira, e parlamentares provenientes do Movimento Democrático Brasileiro (MDB), que, apesar de ocupar um lugar desafiante aos setores dominantes do regime autoritário, provinham de "(...) organizações com certo poder de pressão e mobilização das massas" (RODRIGUES, 1990, p. 9).

\section{Concorrência partidária}

\section{Argentina: da renovação peronista ao duhaldismo, através do menemismo}

Após a derrota fundacional de 1983, o PJ entrou em uma senda de reestruturação interna, em parte para responder aos sucessivos episódios do alfonsinismo, em parte pela crítica do interior do partido aos "marechais da derrota”. Figuras como Antonio Cafiero, Carlos Menem e Carlos Grosso levaram adiante a investida de substituir o ramo sindical na condução partidária por uma predominantemente política (CARLES, 2001, p. $272,274,279)$.

Nas primeiras eleições internas do PJ, em julho de 1988, a renovação peronista definiu as principais candidaturas presidenciais entre dois binômios: por um lado, a fórmula do governador de La Rioja, Menem, seguido do prefeito do município de Lomas de Zamora, do Estado de Buenos Aires, Eduardo Duhalde. Por outro lado, o governador de Buenos Aires, Antonio Cafiero e José Manuel De la Sota, de Córdoba. A vitória de Menem-Duhalde com $53 \%$ dos votos dentro do partido, contando com o respaldo dos setores sindicais que outrora conduziam o partido, especialmente das "62 Organizações” lideradas por Lorenzo Miguel, foi a plataforma de decolagem para as eleições presidenciais de 1989, nas quais o discurso de um "velho" modelo estadista, desenvolvimentista e redistributivo foi suficiente para derrotar o candidato radical Eduardo Angeloz, mais alinhado às opções do livre mercado (MCGUIRE, 1996, p. 181). 
Após a vitória nas eleições presidenciais com $47 \%$ dos votos, Menem teve que assumir com antecedência - produto da crise de ingovernabilidade que padecia o alfonsinismo depois da derrota eleitoral de 1987 e 1989 - as questões cívico-militares e o fracasso das sucessivas tentativas de "domar" a crise hiperinflacionária. Durante seus dois primeiros anos de governo, Menem conduziu uma estratégia clássica peronista de relacionamento com as corporações sociais mais poderosas - grupos empresariais, sindicatos e militares -, ao invés de canalizar a representação pela via partidária (PALERMO, 1997, p. 114). Entretanto, o fracasso dessa primeira estratégia levou o menemismo a um caminho oposto, de neutralização e divisão das corporações, entre elas o sindicalismo, que se evidenciou no seu estilo de governo de "tudo ou nada" (PALERMO, 1993, p. 322) e no desmantelamento da matriz Estado-cêntrica anterior (NOLTE, 1995, p. 36-42; LEVITSKY, 2005, p. 202-205).

Dessa maneira, a estabilização macroeconômica e o crescimento do PIB, somado à debilidade e fratura da União Cívica Radical, foram um capital político de grande benefício para que o peronismo menemista ganhasse as eleições de 1991 e 1993 (SERNA, 2004, p. 60-61; ABAL MEDINA e SUARES CAO, 2002, p. 175; COPPEDGE, 2000a, p. 143-144). Entretanto, todas estas mudanças drásticas que impulsionavam Menem significaram uma ruptura com a lógica peronista prévia, tal como se pode ver expressado no seguinte fragmento de Portantiero:

(...) o menemismo luze como seu reverso. A política de nacionalização é substituída pela onda de privatizações mais acelerada e profunda de qualquer latitude; o fetichismo do mercado suprime a centralidade do Estado, os serviços primam sobre a indústria, a "terceira posição" em matéria de relações internacionais é substituída pelo alinhamento automático com os Estados Unidos, o programa redistributivo de justiça social é deslocado e no seu lugar se promove uma concentração brutal da riqueza (PORTANTIERO, 1995, p. 105).

Este giro, associado à modalidade delegativa de fazer política (O’DONNELL, 1997), foi motivo suficiente para que um setor minoritário dentro do partido se cindisse e formasse, em um primeiro momento, o "grupo dos 8" e, logo com a convergência da direção proveniente do Partido Intransigente e do Movimento de Esquerda, o Frente Grande (FG). Este novo partido "neoperonista" obteve em 1993 três deputados nacionais: C. Álvarez 
e G. Fernández Meijide pela Capital Federal, e o cineasta "Pino" Solanas pelo Estado de Buenos Aires (PALERMO e NOVARO, 1998; SERNA, 2004, p. 65).

Em 1994, Menem logrou impulsionar a reforma constitucional que lhe permitiu aspirar à reeleição graças a uma ampla base de apoios, o que impossibilitou a disputa interna no peronismo pelas candidaturas presidenciais para 1995, razão pela qual os opositores ao menemismo dentro do peronismo, encabeçados por O. Bordón (governador de Mendoza desde 1991), concebessem a ruptura com o PJ (NOVARO, 2001, p. 63-65). Bordón formou primeiro seu próprio partido (PAÍS) e logo, diante das eleições presidenciais de 1995, articulou forças com o FG, formando o Frente País Solidário (FREPASO). Nessas eleições, o binômio Bordón-Álvarez (28,8\%) desbancou pela primeira vez do segundo lugar na concorrência partidária, o radicalismo (17\%). Não obstante, não conseguiram deter a inércia vitoriosa do menemismo, que se impôs com Menem-Rouckauf, obtendo 49,9\% dos votos.

Mesmo o regime político menemista parecendo manter-se ileso, o sistema partidário começava a mostrar fortes mudanças, especialmente configurando uma disputa entre menemistas e um novo bloco antimenemisma, formado a partir de 1997 pela convergência da oposição (UCR e FREPASO) na Aliança pelo Trabalho, pela Justiça, e pela Educação. Diante das eleições presidenciais de 1999, depois das infrutíferas tentativas "re-reeleicionistas" do presidente Menem, seus antigos aliados políticos no peronismo, Eduardo Duhalde e Ramón Ortega, sofreram a segunda derrota do PJ durante o período democrático nas mãos da Aliança (encabeçada por De la Rúa-Álvarez), dando-se assim a segunda alternância de poder na história, desde a transição democrática, mesmo não implicando a posteriori numa mudança nos orçamentos macroeconômicos da "convertibilidade" assentados durante o neoliberalismo menemista (MOREIRA, 2006, p. 39).

O governo da Aliança teve curta vida, em primeiro lugar, pela relutância em mudar o modelo econômico que havia rejeitado desde a oposição; em segundo lugar, pela falta de coordenação das ações entre ambas as forças partidárias, considerando suas divergências ideológicas e políticas por um lado; e também pelo isolamento do presidente dos partidos da coalizão (do qual provinha: UCR), e pela vinculação exclusiva com seu entorno político. Estes são alguns motivos para entender sua curta vida no poder (PALERMO e BONVECCHI, 2000). 
A desestruturação da Aliança deixou inumeráveis "órfãos políticos" (TORRE, 2003) que, para as eleições de 2001, se manifestaram de diferentes maneiras, tais como: através da "Bronca Eleitoral"; as novas lideranças "protoradicais", como o caso de Elisa Carrió ou Ricardo López Murphy; pelas diferentes variantes do peronismo, que mostrava signos de fratura interna entre aqueles que ainda reivindicavam a liderança menemista, ou que se enquadravam sob o poder do aparelho bonaerense duhaldista; e os governadores que manifestavam sua pretensão de comandar o peronismo, como foi o caso de J. M. De la Sota, de Córdoba, de A. Rodríguez Saa, de San Luis, e inclusive de J. Sobisch, de Neuquén, entre outros (TORRE, 2003; POUSADELA, 2004, p. 128-131).

Assim, em um marco de fragmentação política, desintegração social, obstinação macroeconômica e lideranças parcimoniosas, a renúncia de De la Rúa, a crise social, o default e o turbilhão de sucessões presidenciais até a chegada do setor majoritário do peronismo configuraram uma "fuit en avant", uma terceira fronteira para a democracia argentina ${ }^{6}$.

\section{Brasil: o PT, da oposição à opção de poder (1982-1998)}

A partir da presidência do General Ernesto Geisel em 1974, o sistema político brasileiro se encaminhou a uma distensão política "lenta, gradual e segura", em palavras do mencionado militar, o que denota o caráter controlado "desde cima" da transição, e consequentemente sua lentidão em perspectiva comparada aos demais casos latino-americanos (MARENCO, 2008, p. 61,71; SERNA, 2004, p. 51; CODATO, 2005, p. 93-96). Seu sucessor, o General João Figueiredo, diante do crescimento da oposição desde a vitória em 1974 do MDB (Movimento Democrático Brasileiro), introduziu uma mudança no jogo partidário, eliminando os partidos criados para a fachada democrática do regime autoritário e regulamentando o surgimento de novas siglas partidárias - que deviam ter fortes níveis de organização e não podiam formar coalizões -, com o qual, de um sistema bipartidário com concorrência limitada, se estimulou a volta ao multipartidarismo.

As antigas forças opositoras (MDB) e oficiais (ARENA) se converteram no PMDB (Partido do Movimento Democrático Brasileiro) e no PDS (Partido

Segundo Aboy Carles (2001), tanto o governo de Alfonsín como o de Menem supuseram a passagem de uma fronteira, de um começo ex novo da democracia argentina, encarnada cada uma delas pelas duas forças tradicionais. É por isso que, em sintonia com esta perspectiva, acreditamos que a crise de 2001 e a posterior eleição de 2003 possibilitaram a travessia de uma nova fronteira da democracia argentina. 
Democrático Social), respectivamente. Mesmo assim, ressurgiram novas expressões partidárias, em sua maioria recuperando a vertente operáriasindical, mesmo que ancoradas em diversas tradições. Assim, por um lado e a partir da tradição trabalhista de Vargas, se dividiram duas forças, o antigo PTB, que proveio de um partido conservador, e o PDT (Partido Democrata Trabalhista) formado pelos seguidores de Brizola, que invocava a continuidade do trabalhismo varguista; e, por outro lado, desde o novo sindicalismo, surgiu o PT (SERNA, 2004 p. 67-68).

Nas eleições de 1982, a estratégia dos militares funcionou, já que foi outorgada a vitória aos principais herdeiros do antigo bipartidarismo (PMDB e PDS), concentrando $82 \%$ das preferências de voto. Como destaca Meneguello (1989, p. 125, 133), naquela ocasião, o desempenho eleitoral do PT foi concentrado territorialmente: sendo eleitos oito deputados federais, os quais na sua maioria provinham de São Paulo; duas prefeituras, uma na região paulista; e dos 117 vereadores, 78 eram paulistas.

Para as eleições de 1985, mesmo que a antiga oposição (setores do MDB, PT e partidos de esquerda, juntamente com a CUT, a CONCLAT e a Comissão de Justiça e Paz da Igreja Católica, entre outros) tenha se mobilizado sob o emblema de "Diretas Já", para impedir a eleição do presidente através do Colégio Eleitoral, não conseguiram impedir a vitória de Tancredo Neves e de José Sarney, sustentada na "Aliança Democrática” formada pelo PMDB e pelo PFL (Partido da Frente Liberal, criado por dissidentes do PDS, em 1985) (KECK, 1991, p. 250; ARTURI, 1995, p. 22).

Nesse momento de múltipla crise do regime militar que se retirava e da Nova República que nascia (CAMARGO, 1989; MAINWARING, 2001, p. 143), foi convocada uma Assembleia Constituinte no ano de 1988. Nesta conjuntura, no plano partidário, surgiu o PSDB (Partido da Social Democracia Brasileira), fundado por um grupo dissidente à direção do PMDB. Para o PT, este momento significou uma conjuntura de debate respeito ao perfil do seu eleitorado, gerando assim uma mudança para uma estratégia policlassista e com pretensões eleitorais (KECK, 1991, p. 258). Além disso, no plano político-sindical, implicou no reconhecimento do direito ao trabalho, à liberdade sindical, e ao direito à greve.

Em 1989, em um processo de crescente deterioração econômica, forte subida da inflação, e descrédito do governo, as primeiras eleições diretas a presidente depois de trinta anos colocaram Fernando Collor de Mello 
(30,5\%), do Partido da Reconstrução Nacional (PRN), e Luiz Inácio Lula da Silva $(17,2 \%)$, do PT, na disputa do segundo turno. Este foi ganho pelo jovem governador de Alagoas, que com uma forte presença midiática e um poderoso discurso antipolítico e partidário obteve 53\% dos votos, contra 47\% de Lula (MAINWARING, 2001, p. 145-146).

Poucos anos depois, após as políticas econômicas neoliberais do governo de Collor, que não puderam frear a inflação, a dificuldade presidencial em conjugar uma maioria de governo no Congresso, e a impugnação do mandato do presidente (impeachment), uma nova oportunidade de chegar ao poder surgiria para o PT nas eleições presidenciais de 1994. Entretanto, conforme afirma Coppedge (2000a, p. 129-130), naqueles países em que a inflação havia sido excessivamente elevada, os eleitores tenderam a valorizar os partidos que estavam atribuídos ao crédito de solucionar esse problema e possibilitaram o crescimento econômico. Isto ocorreu no Brasil com a figura de Fernando Henrique Cardoso (PSDB), que, como Ministro da Fazenda no mandato de Itamar Franco (substituto de Fernando Collor), pode deter a espiral inflacionária por meio do Plano Real, obtendo a vitória eleitoral à presidência em 1994 - processo similar ao que experimentou Argentina com a reeleição de C. S. Menem em 1995.

A popularidade do Plano Real e de Cardoso não deteve a lenta ascensão do PT, que em 1994 aumentou sua presença na Câmara de Senadores e Deputados, elegeu pela primeira vez dois governadores no interior do país (Espírito Santo e Distrito Federal); e nas eleições municipais de 1996, apesar de perder nos principais centros urbanos que já governava (como Belo Horizonte, Goiânia, Santos, Diadema, entre outros), conseguiu manter-se no poder em cidades como Porto Alegre e Belém do Pará, e inclusive a duplicar a quantidade de prefeituras conquistadas (passou de 54 a 115), na sua grande maioria em cidades de menos de 50 mil habitantes em Estados do interior do país (AMARAL, 2003, p. 125).

Nas eleições presidenciais de 1998, produto da inércia da estabilização econômica que influenciou os cidadãos a eleger entre "FHC ou o caos", Cardoso conquistou a reeleição imediata frente ao projeto Estado-desenvolvimentista, produtivo e regulador dos conflitos, que propunha o PT (MENEGUELLO, 1998, p. 168; AMARAL, 2003, p. 130). Apesar de não conseguir de maneira leninista o poder do "Palácio de Inverno", o PT continuou seu crescimento gramsciano na "guerra de trincheiras": cresceu para três os governos estadu- 
ais (Mato Grosso do Sul, Acre e Rio Grande do Sul), passou de cinco a sete senadores e de 49 a 58 deputados no âmbito federal entre 1994 e 1998 . Ou seja, se posicionou como o principal partido de oposição e, dessa maneira, a principal opção de poder à "Nova" Aliança Democrática que propunham o PSDB-PFL, diante das eleições presidenciais de 2002.

\section{Lógica da concorrência sindical Argentina: a CGT na polifonia do concerto sindical}

Mesmo que poderosos em seu conjunto, o sindicalismo peronista em 1983 se encontrava fragmentado em seu interior, entre aqueles que pertenciam à CGT Azopardo e à CGT Brasil, e paralelamente às “62 Organizações”. Esta última era a que tinha maior preeminência política, ao impor a candidatura de Italo Luder à presidência nacional em 1983, de Lorenzo Miguel (Secretário Geral das “62 Organizações”) à presidência do PJ, ou também de conduzir à presidência da bancada partidária na Câmara de Deputados nas eleições de 1983, a Diego Ibáñez, do Sindicato dos Petroleiros.

A derrota eleitoral e a consequente renovação peronista dividiram o sindicalismo em relação direta com as diferentes fraturas políticas internas do peronismo. Dessa maneira, durante o período da "renovação peronista", o setor dos “25” liderados pelo Secretário Geral da CGT, Saúl Ubaldini (Sindicato dos Cervejeiros), apoiou a candidatura de Antonio Cafiero, e a antiga ala "participacionista” e as “62 Organizações" "miguelistas” deram seu apoio à Menem. As transformações da política - uma vez que o presidente contradisse sua prédica de levar adiante sua "revolução produtiva" - foram um novo motivo para a fratura interna da CGT. Em inícios da era menemista, recuperando a informação dada por Arturo Fernández (FERNANDEZ, 1993, p. 22-23; 1998, p. 209 e seguintes) era possível identificar ao menos quatro setores:

a) CGT San Martín, liderada por Guerino Andreoni (Sindicato dos Empregados do Comércio), que abrangia os setores dos " 25 ", do "miguelismo" (municipais e operários da carne), do "ubaldinismo" (União do Pessoal Civil da Nação - UPCN, e União Operária da Construção - UOCRA) e aqueles que haviam formado a Mesa de Enlace Sindical "Menem Presidente" (entre os que se encontravam, estavam os gastronômicos de Luis Barrionuevo).

b) CGT Azopardo: encabeçada por S. Ubaldini e apoiada por grêmios como a Confederação de Trabalhadores da Educação da República Argen- 
tina (CTERA), Associação de Trabalhadores do Estado (ATE), Federação Argentina de Trabalhadores das Universidades Nacionais (FATUN), a União dos Tranviarios Automotor (UTA), Sindicato dos Caminhoneiros, A Fraternidade, e Sindicato Telepostal (Correios). Deste setor, como será visto, surgiram durante os anos 1990 as principais vozes opositoras ao sindicalismo menemista, dando lugar à CTA por um lado (principalmente ATE e CTERA) e ao MTA (que reuniu aos setores vinculados ao transporte).

c) "Miguelismo": no qual confluíam grêmios de grande peso em términos de afiliação sindical, como a União Operária Metalúrgica (UOM), Sindicato Único dos Petroleiros do Estado (SUPE), Obras Sanitárias, entre outros.

d) "Independentes", no qual estavam grêmios como Luz e Força, Bancários e Empregados do Comércio, que, ainda que permanecessem mais próximos ao menemismo, não ofereciam seu apoio de maneira explícita e incondicional.

Em consonância com a mudança de enfoque menemista às corporações em 1991, o sindicalismo que se encontrava sob o "guarda-chuva" da CGT produziu um novo reagrupamento. Em primeiro lugar, possibilitou a reunificação da CGT em 1992, graças ao "diálogo" entre os setores comandados por Ubaldini e Miguel, que colocaram na cúpula da CGT os sindicalistas provenientes de grêmios de grande porte, como Naldo Brunelli (1992-1993) dos metalúrgicos, Antonio Cassia (1994-1995) dos petroleiros, Gerardo Martínez (1995-1996) da construção, entre outros.

Em segundo lugar, geraram uma nova divisão entre: a) sindicalistas "menemistas puros" que participaram como sócios estratégicos nos processos de privatização; b) os sindicatos "gordos", em geral provenientes do setor privado, os quais se encontravam mais próximos do duhaldismo e buscavam certa autonomia do Estado menemista, e ao mesmo tempo procuravam conservar sua força em relação ao mundo empresarial; c) "sindicalistas peronistas ortodoxos", que pretendiam recuperar o caráter medular dentro do peronismo que o menemismo lhes negava; e d) os sindicatos em "oposição aberta ao neoliberalismo menemista"; entre eles se encontravam os sindicatos baseados na versão social-cristã divulgada pela CLAT (Central Latino-americana de Trabalhadores), sindicatos com uma forte ideologia de esquerda e sindicatos com forte pujança no marco das reformas neoliberais, mas que não tinham presença no ápice da CGT (GODIO, 2006, p. 
104; RODRIGUEZ e ROSELLO, 2001, p. 190-191; MURILLO, 2005, p. 185, 202; FERNANDEZ, 1993, p. 26).

Dentro da ala opositora à direção da CGT, surge em 1991 um novo setor sindical em manifestação à insatisfação com a política de ajuste menemista e a posição da CGT ao respeito. Assim, convergem diversos setores ideológicos, que vão desde o social-cristianismo, a social-democracia e setores independentes de esquerda (FERNANDEZ, 1993, p. 24, 58). No final de 1992, estes romperam com a CGT e criaram o Congresso dos Trabalhadores Argentinos - tendo à CUT brasileira como modelo de referência -, que a partir de 1995 se denominou Central dos Trabalhadores Argentinos (CTA). A princípio, a vinculação da CTA com a política foi com a Frente Grande (e consequentemente com a FREPASO), devido ao fato de que, entre o "grupo dos 8" deputados dissidentes do peronismo que encabeçava "Chacho" Álvarez, se encontrava o deputado Germán Abdala, sindicalista da ATE e um dos ideólogos e líderes da CTA, até seu falecimento em 1993 (RAUBER, 1998, p. 286-287). Ainda que a CTA mantivesse, a partir de 1997, uma maior proximidade com a Aliança, não supôs maior presença interna na formação partidária, mas sim um diálogo público ao compartir a oposição ao menemismo (RODRIGUEZ e ROSELLO, 2001, p. 192).

Durante todo o período menemista, a CTA foi o setor sindical de maior resistência às políticas promovidas pelo presidente, evidente nas diversas manifestações "não convencionais" (como bloqueios em estradas, apagões, formação do movimento dos desempregados, entre outras medidas), mas, sobretudo naquelas manifestações públicas como a "Marcha Federal” (1994) e a instalação da "Barraca Branca" dos docentes na Praça do Congresso da Nação (desde 1997 a 1999), em que a exigência original havia sido a reforma educativa, e que rapidamente se converteu na arena pública dos setores de oposição (GODIO, 2006, p. 107).

O desacordo com a postura de subordinação ou negociação da CGT - tal como demonstra Murillo (1997 e 2005) - não somente foi externa a ela, senão também proveio do seu interior, devido à formação em 1994 do Movimento dos Trabalhadores Argentinos (MTA), liderados por Hugo Moyano (Sindicato dos Caminhoneiros) e Manuel Palacios (UTA). Este setor tinha a capacidade de paralisar a produção, considerada como força nos Sindicatos de Transporte Automotor Público e Privado. Mesmo assim, seu 
posicionamento se fundava na oposição (tal como a CTA) à nova ortodoxia do peronismo menemista, à subordinação dos "sindicatos menemistas", e à direção que desde 1997 mantinha os "Gordos" no interior da CGT; contudo não rompiam com a identidade peronista, como se pôde observar nas eleições de 1999, em que deram seu apoio à candidatura de Duhalde - entretanto, a CTA implicitamente o fez pela Aliança (GODIO, 2006, p. 105, 106).

Dessa maneira, ainda que seja possível entender a perda da força sindical, produto do enfraquecimento nos anos 1990 das bases que estruturavam uma sociedade trabalhadora com pretensões de pleno emprego, como foi o caso da Argentina até metade dos anos 1980, é inegável que as reações sindicais a respeito estavam longe de ser unívocas, e para entendê-la é necessário reconhecer o componente político das divisões no interior e no exterior da CGT, com a qual as eleições de 2003, igualmente no plano partidário, supuseram uma nova fronteira ao mundo político-sindical, ponderando a polifonia que ali reinava.

\section{Brasil: a presença da CUT no mundo sindical na década de 1980 e 1990}

Apesar de a lei que regulava o mundo sindical, prévia à Constituinte de 1988, não ter permitido a criação de organizações sindicais nacionais (como a CGT argentina), isso não impossibilitou o agrupamento informal de sindicatos no âmbito nacional, tal como sucedeu com a CUT em 1983. Durante as décadas de 1980 e 1990, a CUT posicionou-se como a principal estrutura sindical do Brasil, devido ao seu alcance nacional e à composição heterogênea do sindicalismo que a constitui, já que no seu início esteve impulsada pelos setores metalúrgicos do "cinturão vermelho" do ABCD Paulista, e com o tempo foi incorporando os sindicatos do mundo rural - com a afiliação da Confederação Nacional dos Trabalhadores da Agricultura (CONTAG) -, e aquelas expressões sindicais ligadas aos serviços (evidente, por exemplo, a força da CUT no setor dos bancários) e ao emprego público (particularmente forte no sindicalismo dos docentes) (RADERMACHER e MELLEIRO, 2007, p. 125, 128).

A CUT não foi a única construção sindical com pretensões nacionais que se fundou do agitado período das reivindicações sindicais dos anos 1970 e da transição democrática dos anos 1980. Aquele setor que havia ficado por fora da criação da CUT, nas discussões do começo dos anos 1980, como os que estavam ligados a ambos os partidos comunistas (PCB e PC do B), 
aos setores do $\mathrm{PMDB}$, e àqueles agrupados em torno da figura de Antônio Rogério Magri ${ }^{7}$, decidiu convocar também sua própria CONCLAT, que em 1986 permitiu a fundação da Central Geral dos Trabalhadores (CGT). Desde seus inícios, esta central, tentando seguir os passos da AFL-CIO estadunidense, propôs um "sindicalismo de resultados", aspecto que pretendia tirar toda carga ideológica (e política) às reivindicações sindicais, o que permite entender seu caráter negociador (e neste ponto similar à estrutura corporativa dos pelegos do período 1930-1964) e, como decorrência, a diferença substantiva com o "socialismo" da CUT, seu laço com o PT e no reiterado uso da greve geral como estratégia (RODRIGUES, 1991, p. 35).

Entretanto, esse apoliticismo da CGT entrava em clara tensão com aqueles setores ligados aos partidos comunistas (PCB e PC do B), que em desvantagem diante dos seguidores de Magri se separaram da CGT para fundar em 1989 a CSC (Corrente Sindical Classista), que depois se uniu à CUT. Assim, o enfrentamento entre os liderados pelo presidente dos eletricistas e aqueles ligados ao PCB encabeçados por Joaquinzão debilitou ainda mais a CGT, já que terminou unindo-se à CUT.

Contudo, o enfraquecimento da CGT não se deteve aí, já que, em 1991, quando seu líder Magri passou a ocupar o cargo de Ministro do Trabalho durante a presidência de Fernando Collor de Mello, um novo setor liderado por Luiz Antônio Medeiros fundou uma nova estrutura sindical nacional: a Força Sindical (FS). Dessa maneira, a FS reuniu a maioria dos outrora sindicatos fortes da CGT, eletricistas, metalúrgicos, empregados do comércio da cidade de São Paulo e a Federação de Trabalhadores da Alimentação, o que a converteu na segunda central sindical do Brasil (DI TELLA, 2003a, p. 233-235 e 1998, p. 173-175; RADERMACHER e MELLEIRO, 2007, p. 126). O panorama das centrais sindicais durante as décadas de 1980 e 1990 se encerra com o surgimento da CAT (Central Autônoma de Trabalhadores) em 1995, ligada à CLAT (Confederação Latino-americana de Trabalhadores), de vertente social-cristã, e o surgimento da SDS (Social Democracia Sindical) ligada ao PSDB, de caráter pouco expressivo no concerto sindical.

No final dos anos 1970 e durante os anos 1980, com os problemas que a inflação e os aspectos macroeconômicos lhes acarretavam, os movimentos sindicais lutaram pela redemocratização do sistema político, pela liberaliza-

Presidente do Sindicato dos Eletricistas de São Paulo. 
ção dos direitos sociais e trabalhistas que o regime autoritário havia restringido (aspectos que foram sanados em grande medida pelo caráter social da Reforma Constitucional de 1988); já durante os anos 1990, a diretriz da CUT se concentrou na defesa do trabalho, em frear as tentativas de liberalização do mercado, a privatização das empresas e a desregulação do trabalho.

Neste sentido, em alguns momentos a CUT esteve acompanhada pela FS, como por exemplo durante o governo de Fernando Collor. Não obstante, durante a era Cardoso, o papel da CUT foi o de opositor a todas as tentativas do sociólogo para desarticular as prerrogativas sindicais e seus mecanismos de diálogo, tais como as Câmaras Setoriais, o Fórum Nacional sobre Contrato Coletivo e Relações de Trabalho, as tentativas de "flexibilizar" os direitos sociais expressados no Artigo $7^{\circ}$ da Constituição Federal, entre outras tantas medidas de característica neoliberal (RADERMACHER e MELLEIRO, 2007, p. 127; VERAS DE OLIVEIRA, 2005, p. 45-47; GONÇALVEZ, 2003, p. 104-111). Assim, a CUT deixou de lado seu papel proativo dos anos 1980 para ocupar um papel defensivo, radicalizando muitas vezes sua postura, até mesmo além do postulado político-partidário petista que apoiou sistematicamente no discurso político. Entretanto, no plano sindical, esse radicalismo lhe custou a perda de espaço perante a "opção moderada" que exercia a FS (DI TELLA, 1998, p. 176).

\section{Dinâmica interna dos partidos e presença sindical Argentina: o esvaziamento sindical do PJ}

O poder político dos sindicatos na vida partidária argentina não somente obedeceu ao grau de homogeneidade interna sindical, ou à presença ou não do partido afim no governo, mas também no nível de incidência naquele partido que, desde suas origens, havia monopolizado a representação política do interesse sindical, como o foi o Partido Justicialista (PJ).

Enquanto no PJ existiu uma liderança política sobre o mundo sindical, a capacidade de incidir na vida interna do partido por parte da CGT esteve limitada, primeiramente aos desígnios de Perón (1945-1955), depois aos vetos que este impunha, uma vez que havia se distanciado do poder (1955-1973), ou inclusive aos legados que a estrutura partidária havia herdado, após seu falecimento (1973-1976). Nos momentos em que a liderança política se debilitava, a incidência sindical no PJ crescia, sendo este fato evidente durante os primeiros anos da democracia inaugurada em 1983. Foram justamente 
a "renovação" política do peronismo, a instauração de uma nova liderança política (encabeçada por Menem durante os anos 1990, e compartilhada com Duhalde no final da década e início do século), somado aos demais fatores que impactaram o mundo sindical (mudança da matriz Estado-cêntrica e fragmentação do sistema sindical), o que explicam a "desindicalização do PJ" nas duas últimas décadas do século XX, contrariamente ao que sucedeu no Brasil, como veremos, onde o PT manteve sua morfologia sindical, mas mudou a substância de sua composição.

Se observarmos a participação dos setores sindicais na vida interna do justicialismo, podemos reconhecer como durante o governo de Alfonsín sua primazia no Conselho Nacional do partido era manifesta, ao dispor direta ou indiretamente a liderança: até 1984 nas mãos do dirigente metalúrgico L. Miguel, que substituiu D. Bittel como titular do Conselho, logo presidido por dirigentes afins às “62 Organizações”, como J. M. Vernet, H. Iglesias ou V. Saadi. Com o triunfo dos "renovadores” em 1987 a mãos de A. Cafiero, e dos irmãos Carlos e Eduardo Menem a partir de 1989, se produziu um desequilíbrio entre o peronismo sindical e o peronismo político, restabelecendo a primazia política sobre a sindical, como nas épocas de Perón, mesmo que, diferentemente dos anos 1990, o sindicalismo não fosse um dos atores protagonistas do menemismo (GUTIERREZ, 2001, p. 95; ABOY CARLES, 2001, p. 275; MUSTAPIC, 2002, p. 150, 151).

Durante a "renovação peronista" se deslegitimou e se desinstitucionalizou a prática informal do "um terço sindical", segundo a qual o mundo operário-sindical (e as “62 Organizações” como seu representante político) dispunha de um terço das candidaturas internas e gerais (LEVITSKY, 2005, p. 147, 155-158). Durante o biênio de A. Cafiero no partido, nos casos em que se deu cabida aos representantes sindicais, este forçou a mudança do peso corporativo, elegendo representantes daqueles setores contestatários (“os 25”) à linha principal da CGT (as “62 Organizações”). Durante os anos do menemismo, este criou seu próprio trançado sindical (criando a "Mesa Sindical Menem Presidente"), chegando até a modificar a Carta Orgânica do partido para designar-lhe somente 17 dos 110 membros no Conselho Nacional, sem especificar a modalidade de eleição (GUTIERREZ, 2001, p. 96-97).

O desgaste do sistema de "um terço sindical" pode ser melhor refletido na evolução da porcentagem de sindicalistas nos cargos legislativos obtidos pelo peronismo nos anos 1980 e 1990. Apesar de o PJ ter tido, em inúmeras 
oportunidades, a maioria legislativa, a presença sindical no bloco deste partido passou a representar $20 \%$ durante os anos 1980, com uma primeira redução nas legislativas de 1991 (alcançando 15\%), e logo transformou-se em uma presença testemunhal durante o resto dos anos 1990, já que não superou nunca os $8 \%{ }^{8}$. A particularidade foi que em 1997, quando concluiu o mandato de N. Brunelli (UOM), pela primeira vez desde 1983, não havia um representante sindical do setor metalúrgico na bancada peronista (GUTIERREZ, 2001, p. 99; LEVITSKY, 2005, p. 180, 186).

A redução da presença sindical tradicional ligada ao mundo industrial, aspecto que compartilhou em certa medida com a virada do Blue ao White Collar que se produziu no PT nos anos 1990, pode ser observado com maior grau de evidência se considerado o seguinte quadro:

Tabela 1 - Sindicalistas eleitos para a Câmara de Deputados da Nação pelo PJ nos cinco distritos industriais maiores do país entre 1983-2001

\begin{tabular}{c|c|c|c|c|c|c|c|c|c|c}
\hline Distritos & 1983 & $\mathbf{1 9 8 5}$ & $\mathbf{1 9 8 7}$ & $\mathbf{1 9 8 9}$ & $\mathbf{1 9 9 1}$ & $\mathbf{1 9 9 3}$ & $\mathbf{1 9 9 5}$ & $\mathbf{1 9 9 7}$ & $\mathbf{1 9 9 9}$ & $\mathbf{2 0 0 1}$ \\
\hline Capital Federal & 3 & 1 & 1 & 2 & 1 & 1 & 0 & 0 & 0 & 0 \\
\hline Buenos Aires & 10 & 3 & 6 & 4 & 4 & 3 & 2 & 2 & 1 & 1 \\
\hline Córdoba & 1 & 1 & 0 & 1 & 1 & 0 & 0 & 0 & 0 & 0 \\
\hline Mendoza & 1 & 0 & 1 & 0 & 0 & 0 & 0 & 0 & 0 & 0 \\
\hline Santa Fé & 4 & 2 & 1 & 2 & 2 & 0 & 0 & 0 & 0 & 0 \\
\hline Total & 19 & 7 & 9 & 9 & 9 & 4 & 2 & 2 & 1 & 1 \\
\hline
\end{tabular}

Fonte: Levitsky (2005, p. 185).

A desindicalização do peronismo menemista se pode ver manifestada na escassa presença (três membros) no gabinete nacional de Menem, composto por 8 ministros e 39 funcionários com rango de secretário de Estado. Entre os sindicalistas do gabinete, sobressaiu-se o dirigente do Sindicato dos Plásticos e Ministro do Trabalho, Jorge Triaca, que pertencia ao setor "participacionista" durante o regime autoritário e opositor a Ubaldini ao interior da CGT, o que mostra claramente quais sócios sindicais priorizou o menemismo (GUTIERREZ, 2001, p. 104). 
Ainda que a queda da representação sindical peronista supusesse uma queda global da presença sindical na política, não obscureceu outros processos de vinculação partidário-sindical. Se, como vimos, o "grupo dos 8" contava com a presença de G. Abdala (ATE) e Luis Brunati (sindicalista da União dos Docentes Argentinos, de Merlo entre 1973-1975), em 1994 durante a Assembleia Constituinte - a quantidade de sindicalistas no bloco que formava a Frente Grande tinha sindicalistas como Ramón Dubini, da ATE-Entre Ríos, e Alberto Picchinini, da UOM-Villa Constitución. Inclusive, em 1997, se observamos a composição interna do bloco de deputados da FREPASO composto por 38 congressistas, 10,5\% deles era de vertente sindical (LEVITSKY, 2005, p. 196), com o qual se pode observar como a desindicalização do peronismo e sua fragmentação durante a década de 1990 habilitaram a configuração de novos espaços em que sindicalismo e política se relacionavam uma vez mais.

\section{Brasil: transformações ao interior do sindicalismo e do petismo}

Desde suas origens o PT é uma rara avis dentro do concerto partidário brasileiro, caracterizado pela alta indisciplina partidária, forte presença de infidelidade partidária ("transfuguismo") e falta de institucionalização organizativa da grande maioria dos partidos (PALERMO, 2000; MAINWARING, 2001, p. 182; RODRIGUES, 2002, p. 25-37).

Desde seu quinto Encontro Nacional (ENPT-1987), o PT moldou sua estrutura para a concorrência interna, buscando que a diversidade de opiniões pudesse ser exposta por meio de canais que institucionalizassem o conflito. Para tal, possibilitou que os afiliados se agrupassem somente ao interior do partido, sem poder utilizar a legenda do partido para identificar-se, e que as alas existentes ao interior do PT respeitassem as decisões da maioria.

Durante a década dos anos 1990, a divisão do interior do partido respondeu a um fracionamento entre uma ala revolucionária de esquerda e uma ala reformista, mas que superaram essa contradição em prol de manter a governabilidade na qual o PT era governo, além do fato de existir um setor majoritário denominado "Articulação Unidade na Luta", que manteve sempre o comando partidário. Este último teve um acionar pragmático liderando a maioria dentro do PT e buscando avançar politicamente sem gerar fraturas partidárias. Baseando-se nas contribuições de Lacerda (2002), é possível destacar que os expoentes mais conhecidos deste grupo são: Luiz 
Inácio Lula da Silva, José Dirceu (Deputado Federal por São Paulo e Presidente do PT a partir de 1995), Aloizio Mercadante (Deputado Federal por São Paulo em 1991-1994 e 1999), Vicente Paulo da Silva (ex-presidente da CUT), Marco Aurélio Garcia, Eduardo Suplicy e Benedita da Silva (vicegovernadora eleita do Rio de Janeiro em 1998), entre outros.

O setor situado mais à esquerda dentro do PT era a ala "Na Luta PT", que se extinguiu em 1995, cujos principais expoentes eram Luiz Eduardo Greenhalg (Deputado Federal até 1997), Ronald Rocha, Markus Sokol e Edmilson Rodrigues (Prefeito de Belém do Pará a partir de 1996). Dentro da esquerda partidária, se encontra também o grupo denominado "Democracia Socialista”, de origem trotskista, cujos expoentes principais eram: João Machado, Joaquim Soriano, Heloísa Helena (Deputada Federal a partir de 1995 e Senadora eleita por Alagoas em 1998) e Raul Pont (Deputado Federal e Prefeito eleito de Porto Alegre em 1996).

A última agrupação de esquerda era "Articulação de Esquerda", composta por setores que se dividiram em 1993 da corrente majoritária. Suas principais figuras eram: Rui Falcão (Deputado Estadual por São Paulo, eleito em 1990 e 1994), Cândido Vacarezza (Deputado Federal a partir de 1995), Arlindo Chinaglia (eleito por São Paulo Deputado Estadual em 1990 e Federal em 1994 e 1998), Sônia Hypólito (Deputada Federal), Adão Pretto (Deputado Federal pelo Rio Grande do Sul) e Luciano Zica.

No bloco situado à direita da "Articulação Unidade na Luta", e que também o apoiava, se encontrava a "Democracia Radical", setor pragmático decidido a promover alianças com os partidos de centro, dentro do leque de opções partidárias. Seus principais líderes foram: José Genoíno (Presidente do PT no início do governo Lula), Marina Silva (Deputada Federal 1993-1997, e Senadora eleita pelo Acre em 1994) e Tarso Genro (Deputado Federal e Prefeito de Porto Alegre, eleito em 1992).

Apesar dessa diversidade interna, na sua história previa a chegada de Lula na presidência em 2002, se produziram poucas migrações partidárias em bloco, já que o custo parecia ser excessivamente alto. O único exemplo destacado durante o período de estudo foi a saída em 1992 da tendência "Convergência Socialista", que depois formaria o PST-U (Partido Socialista dos Trabalhadores Unificado). Entretanto, resultou um mal endêmico no PT a saída de modo individual de importantes figuras da sua direção. 
Em relação à diversificação do PT e seu componente sindical originário, em um primeiro momento quem exercia a vanguarda do partido reunia-se aos setores relacionados com o trabalho manual, cuja expressão simbólica era os dirigentes provenientes do novo sindicalismo. Contudo, este componente foi se modificando, como ressalta Meneguello (1989, p. 69), no período de formação do PT, não menos de $50 \%$ das Comissões Nacionais Provisórias pertenciam ao grupo dos sindicalistas. Entre os 12 sindicalistas que estavam presentes nas Comissões em 1979, dois eram provenientes do sindicalismo dos professores, um dos bancários e os demais dos sindicatos que agrupavam os trabalhadores manuais. Porém, quase uma década depois, em 1987, essa relação se viu alterada, já que existia uma menor presença de representantes provenientes do trabalho manual e um crescimento de dirigentes oriundos de setores médios, como se pode observar a continuação.

Tabela 2 - Profissões dos membros da Comissão Executiva Nacional (eleita noV ENPT em 1987)

\begin{tabular}{c|c}
\hline Professores & 5 \\
\hline Advogados & 4 \\
\hline Bancários & 3 \\
\hline Metalúrgicos & 3 \\
\hline Jornalistas & 2 \\
\hline Economista & 1 \\
\hline Poeta & 1 \\
\hline Operário & 1 \\
\hline Total & 20 \\
\hline
\end{tabular}

Fonte: Rodrigues $(1990$, p. 18, 20).
Tabela 3 - Profissões dos Deputados do PT na Câmara Federal (eleições de 1986)

\begin{tabular}{c|c}
\hline Professores & 5 \\
\hline Metalúrgicos & 2 \\
\hline Bancários & 2 \\
\hline Economistas & 2 \\
\hline Médicos & 2 \\
\hline Advogado & 1 \\
\hline Assistente Social & 1 \\
\hline Topógrafo & 1 \\
\hline Total & 16 \\
\hline
\end{tabular}

Fonte: Rodrigues (1990, p. 18, 20).

Ademais, como aponta Rodrigues (1990, p. 20), na totalidade dos deputados eleitos em 1986, a proporção de quem era antigamente sindicalista seguiu sendo forte; entretanto, não como em anos anteriores, já que dos 16 deputados, sete eram sindicalistas, mas três pertenciam ao setor fabril (Blue Collar), majoritário nas origens do PT, e quatro eram do setor White Collar. 
Essa maior presença dos "novos" setores sindicalizados (professores e setores provenientes das profissões liberais) se manteve durante os anos 1990. No entanto, não foi um motivo de quebra do PT (tal como aconteceu na CGT com a CTA, e no peronismo com o FG), mas sim um processo que alterou a morfologia interna do PT, sem que o setor majoritário perdesse o comando partidário e sindical. Essa situação permitiu que o PT mantivesse sua presença como partido com fortes bases sindicais, apesar de as mesmas terem mudado substancialmente.

A estabilidade do laço partidário-sindical que obteve o PT permitiu entender de que maneira (em paralelo ao crescimento do PT como opção de poder no cenário partidário brasileiro) a presença sindical do partido foi crescendo concomitantemente. Esse fato se manifesta, por exemplo, no legislativo: em 1998 a bancada sindical era de 44 representantes; e em 2002, quando se produziu a "revolução sindical do PT" ao aceder ao governo nacional, a bancada sindical chegou a ter 53 deputados, sendo que 44 eram do PT (RODRIGUES, 2004, p. 163).

\section{Conclusões}

A simples vista parece claro que os casos compartilham fortes semelhanças de base, entretanto o contraste de contextos em términos metodológicos que realizamos na presente investigação permitiu desvelar a estrutura que faz perceptível as trajetórias e resultados diferentes que o vínculo partidário-sindical foi adquirindo em um e outro país, produto do advir do mundo partidário, do mundo sindical e do interior do partido de base sindical analisado.

Essas diferenças são evidentes quando se recuperam a comparação entre casos nos diferentes recortes temporais, fazendo uma leitura transversal às diferentes dimensões analíticas propostas (mundo partidário, mundo sindical, interior do partido de base sindical). Em relação à origem: no caso argentino existe um laço partidário-sindical implantado no marco de uma matriz Estado-cêntrica de corte nacional e popular, no qual tem preeminência o ramo político (monopolizado por J. Perón) em relação ao ramo sindical (origem desde cima), que perdura através do tempo, enquanto se reforça ou recupera a liderança política (sindicalização do partido).

No caso brasileiro, a tentativa varguista de ligar política e sindicalismo no mesmo contexto nacional popular ficou truncada, ao não encontrar um sindicalismo fortemente enraizado, nem uma vontade política de alentar 
uma sindicalização total da sua força. A politização do mundo sindical somente foi possível ser conquistada quando, por um lado, o sindicalismo se encontrou com um maior grau de estruturação em meados dos anos 1970 e, por outro lado, quando liderou suas pretensões políticas na via partidária (origem desde baixo), produzindo um partidarismo do sindicato, que derivou na fundação de um partido de base sindical com pretensões eleitorais crescentes, como foi o PT.

Posteriormente, mesmo que ambos os partidos conservassem suas marcas de origem e sua dependência a respeito, a inferência descritiva que propôs esta investigação permitiu observar como o caminho foi diferente, e inclusive foi variável no interior de um mesmo caso. Na Argentina, a preeminência política sob a sindical originária terminou impondo-se na maior parte do período analisado; entretanto, a partir da redemocratização dos anos 1980, se gerou uma mudança de sentido do vínculo partidário-sindical. No Brasil, apesar de ter se mantido a preeminência sindical sob a política durante todo o período posterior à origem do PT - com o qual seria possível relacionar uma forte dependência da origem -, em realidade a relação partidáriasindical foi se alterando através de mudanças graduais no interior do partido, especialmente pela variação do tipo de dirigências sindicais e as mudanças programáticas, que acompanharam a pretensão eleitoral do PT.

Da mesma forma, a evidência apontada pela presente investigação mostra como, além dos diagnósticos recorrentes durante a década dos 1990 que denotavam uma crise de representação sindical e como consequência um claro enfraquecimento da sua presença na arena política, o caso brasileiro (talvez sendo uma exceção neste panorama) demonstrou o contrário. Este caso possibilita pensar que não formam somente fatores estruturais de tipo socioeconômicos os que podiam modificar a presença sindical no cenário político (como costuma ser habitual para pensar a realidade argentina dos anos noventa), mas sim elementos políticos próprios das sequências históricas vividas por cada um dos partidos e sindicatos, os que incidiram claramente nas estruturas de oportunidades políticas do sindicalismo.

A respeito das comparações intra casos, o aspecto de maior relevância no caso argentino é a desindicalização do PJ, processo que se iniciou em meados dos anos 1980, e parece haver alcançado seu ápice na conjuntura eleitoral de 2003. Também, é notável a crescente fragmentação do PJ em relação às novas forças partidárias neoperonistas, seja nos anos 1990 com a Frente 
Grande e a FREPASO, seja no novo século com o surgimento de legendas partidárias como as que encabeçaram A. Rodriguez Saa, N. Kirchner ou Menem, e como esta heterogeneidade peronista se traduziu igualmente na fragmentação sindical ao interior e exterior da CGT.

Contrariamente, no caso brasileiro se observa um processo de fortalecimento positivo do laço partido-sindicato, que facilita compreender por que a chegada do PT em 2002 foi uma "revolução sindical" e por que esse fato não foi um elemento inesperado. Entretanto, mesmo que o relevo em um primeiro plano mostre certa estabilidade na relação partidária-sindical, existem várias mudanças no interior do caso brasileiro, tais como: a) a alteração do tipo de sindicalismo que compõem o PT no seu interior, passando de sindicatos vinculados a setores operário-manuais, a setores ligados ao setor terciário e serviços públicos; b) a modificação na lógica de concorrência política, fazendo com que o PT deixe de ser um partido que se relacionava com outros pares que impulsavam uma mudança desde o marco ideológico da esquerda, para ser um partido que, mesmo que tenha a capacidade de aglutinar as expressões de esquerda, tem manifestado uma clara virada para o centro, fazendo coalizões eleitorais (com o PL) ou ao momento de governar (com o PMDB), com forças de centro-direita.

Para concluir, as questões apresentadas sobre esses dois casos destacam como os caminhos percorridos pelos partidos com fortes raízes no mundo sindical são substancialmente diferentes, e que, em grande medida, isto se explica pela conjuntura original, pelos mecanismos de fortalecimento da senda inicial, e pelas variações ou mudanças que se introduziram, de maneira gradual e capilar, no porvir interno e externo dos próprios partidos e sindicatos em questão.

\section{Referências bibliográficas}

ABAL MEDINA, Juan \& SUAREZ CAO, Julieta. 2002. "La competencia partidaria en la Argentina: sus implicancias sobre el régimen democrático”. In: CAVAROZZI, Marcelo \& ABAL MEDINA, Juan (orgs.). El asedio a la política: los partidos latinoamericanos en la era neoliberal. Rosário: Homo Sapiens.

ABOY CARLES, Gerardo. 2001. Las dos fronteras de la democracia argentina: la reformulación de las identidades políticas de Alfonsín a Menem. Rosário: Homo Sapiens. 
AMARAL, Oswaldo. 2003. A estrela não é mais vermelha: as mudanças do programa petista nos noventa. São Paulo: Garçoni.

ARTURI, Carlos. 1995. "As eleições no processo de transição à democracia no Brasil”. In: BAQUERO, Marcelo (org.). Transição, eleições, opinião pública. Porto Alegre: Ed. UFRGS.

BALBI, Carmen Rosa. 1990. "Sindicato, partido: dilemas de la democracia". Nueva Sociedad, n. 110, p. 101-109.

CAMARGO, Aspásia. 1989. "As dimensões da crise". In: CAMARGO, Aspásia \& DINIZ, Eli (orgs.). Continuidade e mudança no Brasil da nova república. São Paulo: Vértice/Iuperj.

CODATO, Adriano Nervo. 2005. "Uma historia política da transição brasileira: da ditadura militar à democracia”. Sociologia e Política, n. 25, p. 83-106. COLLIER, Ruth \& COLLIER, David. 1991. Shaping the political arena: critical jointures, the labor movement and regime dynamics in Latin America. Princeton: Princeton University Press.

DE RIZ, Liliana. 1986. "Política y partidos. Ejercicio de análisis comparado: Argentina, Chile, Brasil y Uruguay”. Desarrollo Económico, v. 25, n. 100, p. 659-682.

DEL CAMPO, Hugo. 1983. Sindicalismo y peronismo. Buenos Aires: CLACSO.

DI TELLA, Torcuato. 1998. Los partidos políticos: teoría y análisis comparativo. Buenos Aires: AZ.

. 2003a. "El sindicalismo: tendencias y perspectivas". In: Política brasileña contemporánea. PALERMO, Vicente (org.). Buenos Aires: Siglo XXI/IDT-PNUD.

. 2003b. Perón y los sindicatos: el inicio de una relación conflictiva. Buenos Aires: Ariel.

FERNANDEZ, Arturo. 1993. Las nuevas relaciones entre sindicatos y partidos políticos. Buenos Aires: Centro Editor América Latina.

FREIDENBERG, Flavia \& LEVITSKY, Steven. 2007. “Organización informal de los partidos políticos en América Latina”. Desarrollo Económico, v. 46, n. 184 , p. 539-568.

GERMANI, Gino. 1962. Política y sociedad en una época de transición. Buenos Aires: Paidós.

GODIO, Julio. 2006. El tiempo de Kirchner: el devenir de una "revolución desde arriba”. Buenos Aires: Letra Grifa. 
GOMEZ, Ângela Castro \& D'ARAUJO, Maria Celina. 1989. Getulismo e trabalhismo. São Paulo: Ática.

GONÇALVEZ, Carlos Augusto. 2003. "El mundo del trabajo en Brasil. Los desafíos del PT”. In: GODIO, Julio (ed.). ¿Un PT en Argentina? Reformular las formas de pensar la política para entender la experiencia brasileña. Buenos Aires: Corregidor.

GUTIERREZ, Ricardo. 2001. “La desindicalización del peronismo”. Revista Política y Gestión, v. 2. p. 93-112.

JAGUARIBE, Hélio. 1987. “Brasil: su evolución política de 1930 a 1964”. In: DI TELLA, Torcuato (org.). Sociedad y estado en America Latina. $5^{\mathrm{a}}$ ed. Buenos Aires: Eudeba.

KECK, Margaret. 1991. PT, a lógica da diferença: o Partido dos Trabalhadores na construção da democracia brasileira. São Paulo: Ática.

LACERDA, Alan Daniel Reire de. 2002. “O PT e a unidade partidária como problema”. Dados, v. 45, n. 1, p. 39-76.

LEIRAS, Marcelo. 2004. "Organización partidaria y democracia: tres tesis de los estudios comparativos y su aplicación a los partidos en Argentina." Revista SAAP, v. 1, n. 3, p. 515-559.

LEVITSKY, Steven. 2005. La transformación del justicialismo: del partido sindical al partido clientelista. 1983-1999. Buenos Aires: Siglo XXI.

MAINWARING, Scott. 2001. Sistemas partidários em novas democracias: o caso de Brasil. São Paulo: FGV/Mercado Aberto.

\& SCULLY, Timothy. 1996. "Introducción: sistemas de partidos en América Latina”. In: MAINWARING, Scott \& SCULLY, Timothy (orgs.). La construcción de instituciones democráticas: sistemas de partidos en América Latina. Santiago de Chile: CIEPLAN. Disponível em: http:// www.cieplan.cl/inicio/archivo_biblioteca.php?inicio $=41 \&$ page $=41 \&$ filt $=\&$ seccion $=\&$ tipo $=$ \&autor $=\&$ palabra_biblioteca $=\&$ area $=\& \mathrm{mes}=\&$ ano $=$ $\&$ PHPSESSID=bf0891c21c7a7eb518aa5f4fb837eac7 (acessado em 14 de dezembro de 2007).

MARENCO, André. 2008. “¿Despacio se llega lejos? La transición a la democracia en Brasil en perspectiva comparada”. In: ALCÁNTARA SÁEZ, Manuel \& RANULFO MELO, Carlos (eds.). La democracia brasileña: balance y perspectivas para el siglo XXI. Salamanca: Editorial de la Universidad de Salamanca. 
MATSUSHITA, Hiroshi. 1986. Movimiento obrero argentino 1930-1945: sus proyecciones en los orígenes del peronismo. Buenos Aires: Hyspamérica. MCGUIRE, Jerry. 1996. "Partidos políticos y democracia en Argentina”. In: MAINWARING, Scott \& SCULLY, Timothy (orgs.). La construcción de instituciones democráticas: sistemas de partidos en América Latina. Santiago de Chile: CIEPLAN. Disponível em: http://www.cieplan.cl/ inicio/archivo_biblioteca.php?inicio $=41 \&$ page $=41 \&$ filt $=\& \sec$ cion $=\& \mathrm{ti}$ po $=\&$ autor $=\&$ palabra_biblioteca $=\&$ area $=\&$ mes $=\&$ ano $=\&$ PHPSESSID =bf0891c21c7a7eb518aa5f4fb837eac7 (acessado em 14 de dezembro de 2007).

MENEGUELLO, Rachel. 1989. PT: a formação de um partido. 1979-1982. São Paulo: Paz e Terra.

. 1998. Partidos e governos no Brasil contemporâneo (1985-1997). São Paulo: Paz e Terra.

MOISÉS, José Álvaro. 1986. "Partido de massas: democrático e socialista”. In: SADER, Emir (org.). E agora, PT: caráter e identidade. São Paulo: Brasiliense.

MOREIRA, Constanza. 2006. "Sistema de partidos, alternancia política e ideología en el cono sur". Revista Uruguaya de Ciencia Política, n. 15, p. 31-56.

MURILLO, María Victoria. 1997. "La adaptación del sindicalismo argentino a las reformas del mercado en la primera presidencia de Menem". Desarrollo Económico, v. 37, n. 147, p. 419-446.

. 2005. Sindicalismo, coaliciones partidarias y reformas de mercado en América latina. Bueno Aires: Siglo XXI.

MURMIS, Miguel \& PORTANTIERO, Juan Carlos. 1971. Estudios sobre el origen del peronismo. Buenos Aires: Siglo XXI.

MUSTAPIC, Ana. 2002. "Del Partido Peronista al Partido Justicialista: las transformaciones de un partido carismático”. In: CAVAROZZI, Marcelo \& ABAL MEDINA, Juan Manuel (h) (orgs.). El asedio a la política: los partidos latinoamericanos en la era neoliberal. Rosário: Homo Sapiens. NOLTE, Detlef. 1995. "De la larga agonía peronista a la reconversión menemista”. In: HOFMEISTER, Wilhelm \& THESING, Josef (eds.) Transformaciones de los sistemas políticos de América Latina. Buenos Aires: KAS/CIEDLA. 
NOVARO, Marcos. 2001. "El presidencialismo argentino entre la reelección y la alternancia”. In: CHERESKY, Isidoro \& POUSADELA, Inés (orgs.). Política e instituciones en las nuevas democracias. Buenos Aires: Paidós. O’DONNELL, Guillermo. 1997. “Democracia delegativa”. In: Contrapuntos. Buenos Aires: Paidós.

OLIVEIRA, Isabel Ribeiro de. 1988. Trabalho e política: as origens do Partido dos Trabalhadores. Petrópolis, RJ: Vozes.

PALERMO, Vicente. 1993. “El menemismo ¿perdurará?”. Revista Uruguaya de Ciencia Política, n. 6, p. 139-166

. 1997. "Poder, democracia y política en la Argentina de los '90”. In: MALLO, Susana (org.). Ciudadanía y la democracia en el cono sur. Uruguai: FCS-UROU/UNESCO-Grupo Montevideo/Trazas.

. 2000. "Como se governa o Brasil? O debate sobre instituições políticas e gestão de governo". Dados, v. 43, n. 3, p. 521-557.

\& BONVECCHI, Alejandro. 2000. "En torno a los entornos: presidentes débiles y partidos parsimoniosos". Revista Argentina de Ciencia Política, n. 4, p. 103-112.

PALERMO, Vicente \& NOVARO, Marcos. 1998. Los caminos de la centroizquierda: dilemas y desafíos del Frepaso y la Alianza. Buenos Aires: Losada.

PEDROSA, Fernando. 2005. "Las relaciones personales también importan. Instituciones informales, redes y partidos políticos”. Disponível em: http://revista-redes.rediris.es/webredes/arsrosario/02-Pedrosa.pdf (acessado em 14 de dezembro de 2007).

PORTANTIERO, Juan Carlos. 1995. "Menemismo y peronismo: continuidad y ruptura”. In: BORÓN, Atilio; MORA Y ARAUJO, Manuel; NUN, José; PORTANTIERO, Juan Carlos \& SIDICARO, Ricardo (orgs.). Peronismo y menemismo: avatares del populismo en la Argentina. Bueno Aires: El Cielo por Asalto.

POUSADELA, Inés. 2004. "Los partidos políticos han muerto. ¡Larga vida a los partidos políticos!”. In: CHERESKY, Isidoro \& BLANQUER, JeanMarie. ¿Qué cambió en la política argentina? Elecciones, instituciones y ciudadanía en perspectiva comparada. Buenos Aires/Rosário: IHEALUBA/Homo Sapiens.

RADERMACHER, Reiner \& MELLEIRO, Waldeli. 2007. "El sindicalismo bajo el gobierno de Lula”. Nueva Sociedad, n. 211, p. 124-143. 
RAUBER, I. 1998. La discusión social y sindical en el fin de siglo: una historia silenciada. Buenos Aires: Pensamiento Jurídico Editora.

RODRIGUES, Leôncio Martins. 1969. La clase obrera en el Brasil. Buenos Aires: CEDAL.

1990. Partidos e sindicatos: escritos de sociologia política. São Paulo: Ática.

. 1991. "As tendências políticas na formação das centrais sindicais". In: BOITO, Armando (org.). O sindicalismo brasileiro nos anos 80. São Paulo: Paz e Terra.

. 1998. "O declínio das taxas de sindicalização: a década de 80". Revista Brasileira de Ciências Sociais, v. 13, n. 36, p. 41-66.

. 2002. "Partidos, ideologia e composição social". Revista Brasileira de Ciências Sociais, v. 17, n. 48, p. 31-47.

. 2004. "Lula y los cambios en la clase política brasileña". In: RODRIGUES, Leôncio Martins \& SADEK, M. (orgs.). El Brasil de Lula: diputados y magistrados. Buenos Aires: La Crujía/PNUD/ITDT.

RODRIGUEZ, Gloria \& ROSELLO, Diego. 2001. "El sindicalismo latinoamericano ante el desafío del capital globalizado. Análisis de las estrategias actuales de los movimientos obreros argentinos y brasileños en perspectiva comparada". In: PINTO, Julio (org.). Argentina entre dos siglos: la política que viene. Buenos Aires: Eudeba.

SANTANA, Marco Aurélio. 1999. "Entre a ruptura e a continuidade: visões da história do movimento sindical brasileiro". Revista Brasileira de Ciências Sociais, v. 14. n. 41, p. 103-120.

SERNA, Miguel. 2004. A reconversão democrática das esquerdas no cone sul. São Paulo: EDUSC-ANPOCS.

SIDICARO, Ricardo. 1999. "Consideraciones sociológicas sobre las relaciones entre el peronismo y la clase obrera en la Argentinas, 1943-1955". In: MACKINNON, María \& PETRONE, Mario (orgs.). Populismo y neopopulismo en América Latina: el problema de la cenicienta. Buenos Aires: Eudeba.

TORRE, Juan Carlos. 1990. La vieja guardia sindical y Perón: sobre los orígenes del peronismo. Buenos Aires: Instituto Torcuato Di Tella/ Sudamericana.

. 1999. "Interpretando (una vez más) los orígenes del peronismo". In: MACKINNON, María \& PETRONE, Mario (orgs.). Populismo y 
neopopulismo en América Latina: el problema de la cenicienta. Buenos Aires: Eudeba.

. 2003. "Los huérfanos de la política de partidos. Sobre los alcances y la naturaleza de la crisis de representación partidario". Desarrollo Económico, v. 42, n. 168, p. 647-665.

VERAS DE OLIVEIRA, Roberto. 2005. "Diálogo social e a reforma trabalhista e sindical no Brasil: debate atual”. In: ESTANQUE, Elísio et al. (org.). Mudanças no trabalho e ação sindical: Brasil e Portugal no contexto de transnacionalização. São Paulo: Cortez.

\section{Resumo}

O objetivo deste trabalho é analisar o enraizamento do PT no Brasil e do PJ na Argentina, com vista a recuperar as transformações dos próprios atores partidários e sua relação com o sindicalismo. Para fazer isto, observamos: a) a origem das raízes sindicais dos partidos analisados; b) a dinâmica da competição partidária; c) a dinâmica da concorrência sindical; e d) a presença sindical no interior dos partidos em estudo, durante a década de oitenta e noventa. A seleção destas dimensões busca compreender o quanto de "revolução sindical" teve a chegada do PT na presidência da República em 2002 no Brasil, e quanto "dessindicalizado" estava o peronismo no momento da escolha de Néstor Kirchner na Argentina, em 2003.

Palavras-chave: Partido Justicialista; Partido dos Trabalhadores; Confederación General del Trabajo; Central Única dos Trabalhadores; Argentina; Brasil.

\section{Abstract}

The aim of this paper is to analyze the social roots of two political parties (PT in Brazil and PJ in Argentina) in relationship with trade unions (CUT \& CGT). We analyze: a) the origin of the union roots of the parties being analyzed, b) the dynamics of party competition, c) the dynamics of union competition, and d) the presence of unions within those parties during the decade of the eighties and nineties. The selection of these dimensions seeks to understand, on one hand, to what extent the arrival of the PT to the Brazilian Presidency, in 2002, involved some sort of "labor-unionist revolution", and, on the other hand, how much without unionist influence was the Peronismo at the moment of the election of Nestor Kirchner in 2003 Argentina.

Key words: Peronist party; Partido dos Trabalhadores; CGT; CUT; Argentina; Brazil.

Recebido em junho de 2010.

Aprovado em agosto de 2010. 